\title{
In situ conservation of traditional vegetable diversity in Wa homegardens in southwestern Yunnan, China
}

\author{
Hua Shao ${ }^{1}$, Rosemary Hill ${ }^{2}$, Dayuan Xue ${ }^{1 *}$ (D) and Jingbiao Yang ${ }^{1,3^{*}}$
}

\begin{abstract}
Background: Homegardens are in situ conservation sources of germplasm diversity for overcoming homogenous germplasm problems in industrial agricultural systems. The Wa people constitute a long-dwelling ethnic group mainly in southwestern Yunnan with a unique culture and rich knowledge of traditional vegetables. We hypothesized that traditional vegetable varieties are well conserved in Wa homegardens because Wa culture promotes the preservation of traditional vegetables. We surveyed vegetable varieties and the practices that are involved in the conservation of traditional vegetables in Wa homegardens, which could form the basis for in situ conservation.

Methods: The methods were used including questionnaires and semi-structured interviews. Sixty homegardens were surveyed through purposive sampling in 6 Wa villages. We documented ethnobotanical information about vegetables in homegardens. Plant species were identified according to the Flora of China. And thematic analyses were conducted for in-depth interviews to identify the conservation factors for traditional vegetables.

Results: Fifty-two vegetable species belonging to 16 families and 41 genera were recorded from 60 Wa homegardens. Fifty-five traditional vegetable varieties and thirty-six hybrids were recorded. Among all the villages, $23 \pm 6$ (average \pm SD) traditional vegetable varieties per homegarden and $9 \pm 3$ (average \pm SD) introduced varieties per homegarden were recorded. Local seeds were stored in 78\% of households, with an additional 9\% of households' seed supplies coming from neighbors and relatives; the other 13\% of households purchased local seeds from markets. In $83 \%$ of families, the female head was mainly responsible for the decision-making concerning traditional vegetables in homegardens; in 10\% of families, the male head was responsible for decision-making, and a small percentage (2\%) was determined by elderly people. Five percent of families made decisions jointly between male and female household heads.
\end{abstract}

Conclusions: This study demonstrated that rich traditional germplasm diversity is harbored in Wa homegardens because of the unique culture and traditional knowledge of Wa communities, which are practiced daily with homegrown food plants. Local vegetable seed conservation and sharing systems help maintain germplasm diversity in the Wa community homegardens. Wa homegardens constitute a practical solution for protecting traditional germplasm diversity and maintaining traditional lifestyles.

\footnotetext{
*Correspondence: xuedayuan@hotmail.com; yangjingbiao@muc.edu.cn

${ }^{1}$ College of Life and Environmental Sciences, Minzu University of China,

Beijing 100081, China

${ }^{3}$ Key Laboratory of Ecology and Environment in Minority Areas (Minzu

University of China), National Ethnic Affairs Commission, Beijing 100081,

China

Full list of author information is available at the end of the article
} permits use, sharing, adaptation, distribution and reproduction in any medium or format, as long as you give appropriate credit to the original author(s) and the source, provide a link to the Creative Commons licence, and indicate if changes were made. The images or other third party material in this article are included in the article's Creative Commons licence, unless indicated otherwise in a credit line to the material. If material is not included in the article's Creative Commons licence and your intended use is not permitted by statutory regulation or exceeds the permitted use, you will need to obtain permission directly from the copyright holder. To view a copy of this licence, visit http://creativecommons.org/licenses/by/4.0/. The Creative Commons Public Domain Dedication waiver (http://creativeco mmons.org/publicdomain/zero/1.0/) applies to the data made available in this article, unless otherwise stated in a credit line to the data. 
Keywords: Traditional vegetable diversity, In situ conservation, Homegardens, Traditional culture, Wa people

\section{Background}

Traditional vegetables are cultivated varieties that have arisen through a long history of selection and cultivation in small farming systems such as homegardens [1]. As the global population continues to increase, high malnutrition rates, insufficient energy sources, and a lack of essential nutrients such as vitamins continue to be major concerns [2]. However, traditional vegetables, as valuable sources of food and nutritional security, are underutilized and underrepresented in the global conservation system for plant genetic resources [3-5]. With the ongoing expansion of the global market economy and modernization of agriculture, high-yielding hybrid vegetables have become increasingly popular and valued, and the diversity of traditional vegetables is threatened with extinction [6].

Homegardens have been recognized as sources of high vegetable germplasm diversity, which can be essential for overcoming food-security problems, such as the loss of food sources from rapidly spreading diseases associated with homogenous germplasms in industrial agricultural systems [7-10]. Studies have emphasized that homegardens have many attributes related to plant diversity, multiple functions, and other economic benefits for farmers $[11,12]$. These homegardens provide a high diversity of cultivated plants for self-sufficiency and social values underpinning and contributing to cultural diversity [1315]. Furthermore, homegardens are more sustainable and adapted to local demands because of the planting of traditional varieties and the use of traditional management practices [16-18]. Diversity in homegardens can be affected by the interactions among spatial, environmental, demographic, social, economic, and cultural factors to influence agricultural practices $[19,20]$. Gender is another factor that influences ownership and crop diversity in homegardens, and women and older people traditionally take responsibility for homegardens [21, 22].

With a population of approximately 429,700 in China, the Wa people are one of 55 ethnic minorities according to the reports of the sixth national census [23]. Wa people inhabit mainly mountainous areas referred to as the Wa Mountains, which are located in Cangyuan Wa Autonomous County and Ximeng Wa Autonomous County in southwestern Yunnan. The Wa language is an offshoot of the Palaungic branch of the Austroasiatic language family and has no history of written words [24]. Wa villages are located on hillsides, and traditional houses are constructed from thatch, bamboo, and timber. Each house has a fire pit inside to cook food and keep the house warm. Their staple foods are rice, corn, and buckwheat. The traditional belief of the Wa people is animism, and they worship nature, their ancestors, and both animals and plants [25]. The Wa mainly survives on abundant plant resources in the mountains and forests near the villages; they practice swidden agriculture and are involved in hunting and gathering. Wa people have a long history of vegetable farming and foster rich homegardens management practices and knowledge [26].

In southwestern Yunnan Province, homegardens are recognized as small agroecosystems and are used as part of in situ conservation strategies consistent with household socioeconomic practices of other ethnic groups [27, 28]. The region has a diverse ethnic composition, including Wa, Lahu, Dai, and 31 other ethnic minorities. Based on the previously reported influence of socioeconomic conditions among Wa people, traditional vegetable resources are an important part of their dietary culture $[29,30]$. However, Wa homegardens and their management practices for various vegetables have not been reported in the literature.

This study demonstrates the traditional vegetable diversity and factors by which Wa households conserve traditional vegetable resources in their homegardens in Wa villages. Given the importance of traditional vegetables as essential ingredients in the Wa diet, we hypothesized that Wa villagers prefer to plant traditional vegetables and maintain the practices in homegardens because of their traditional culture. We expected to find that Wa people prefer to grow traditional vegetables in their homegardens for self-consumption. Women may take more responsibility for the decision-making of homegardens given the labor distribution among Wa households. And dietary custom and traditional culture could be the main factors to motivate Wa people to plant traditional vegetables. We argue that Wa homegarden management is a promising approach for conserving traditional vegetable resources to maintain dietary diversity and self-sufficiency.

\section{Methods}

\section{Research area}

The research area lies in the mountainous region of the southern part of the $\mathrm{Nu}$ Mountains at the border with Myanmar in the southwestern Yunnan province, China, between the western Lancang River and eastern Salween River (Fig. 1). This area, traditionally known as the Wa Mountains, straddles the Tropic of Cancer and has a subtropical climate with mild weather conditions. Affected 


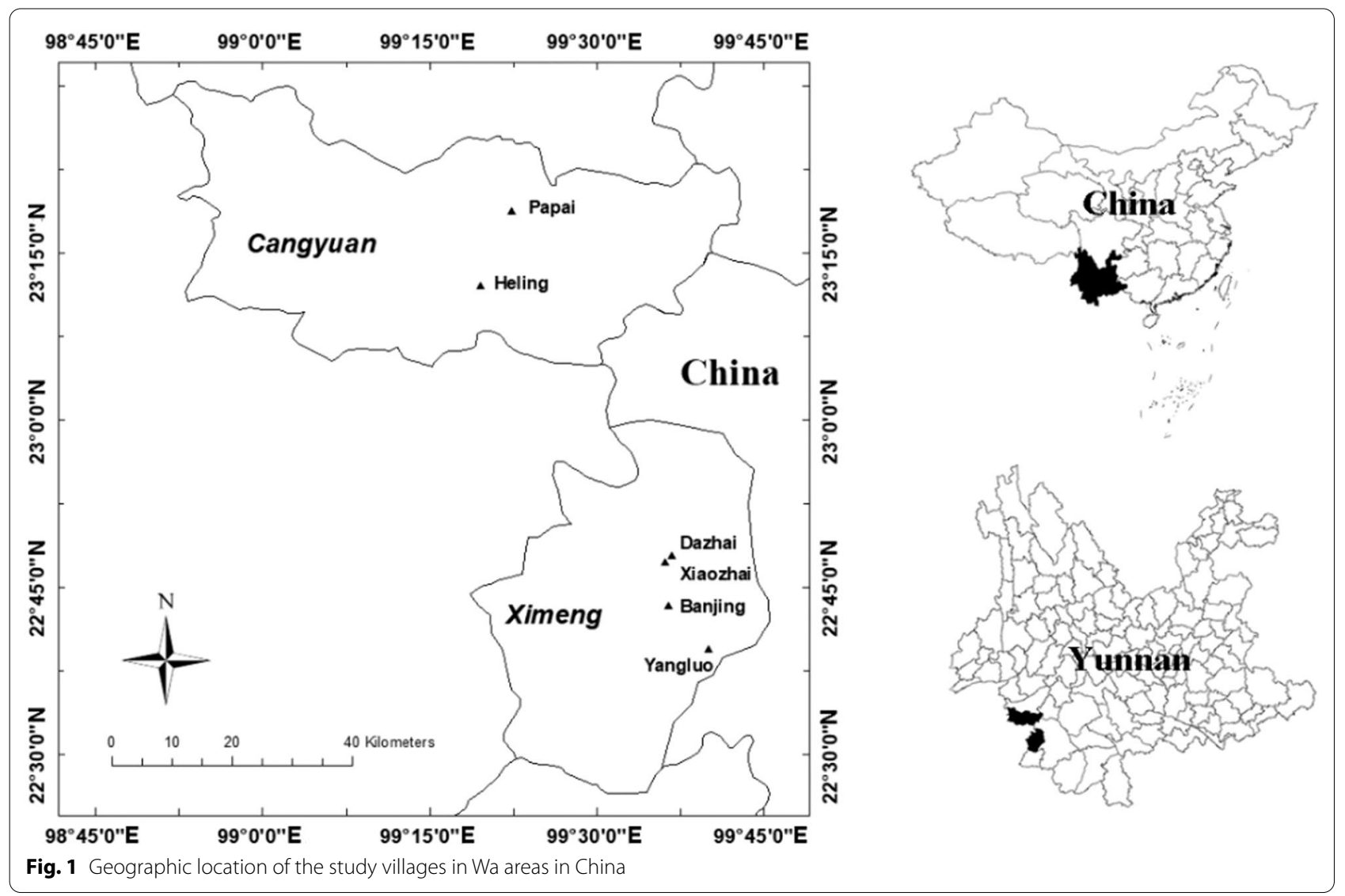

by the warm and wet airflow from the Indian Ocean, rainfall is relatively abundant. The climate is also affected by the topography of this mountainous region.

This study was carried out in six villages of two administrative counties in May 2015, December 2015, May 2017, and December 2019. Cangyuan County is located between $98^{\circ} 52^{\prime}-99^{\circ} 43^{\prime} \mathrm{E}$ and $23^{\circ} 04^{\prime}-23^{\circ} 30^{\prime} \mathrm{N}$. Cangyuan has a subtropical monsoon climate (mild and wet). The average amount of annual sunshine is $1862.5 \mathrm{~h}$, the annual average temperature is $17.7{ }^{\circ} \mathrm{C}$, and the annual average rainfall is $1747.2 \mathrm{~mm}$ [23]. Ximeng County is located between $99^{\circ} 18^{\prime}-99^{\circ} 43^{\prime} \mathrm{E}$ and $22^{\circ} 25^{\prime}-22^{\circ} 57^{\prime} \mathrm{N}$. The region has a subtropical marine monsoonal climate affected by warm and humid conditions southwest of the Bay of Bengal. The annual average temperature is $15.3^{\circ} \mathrm{C}$, and the average amount of annual rainfall is $2758 \mathrm{~mm}$, which is the highest in Yunnan Province. The highest elevation in this region is $2458.9 \mathrm{~m}$ above sea level, and the lowest elevation is $590 \mathrm{~m}$. Due to this climate, the vegetation in these two counties is abundant and diverse, with a forest coverage rate of $37 \%$.

Dazhai village, Xiaozhai village and Banjing village are in Zhongke town, Ximeng County. Yangluo village is in the town of Mengsuo in Ximeng County. Heling and
Papai villages are in the town of Nuoliang in Cangyuan County (Table 1). Six representative villages were selected through discussions with elders, village heads, and local experts from the agricultural bureau in an initial survey visit [31], because these villages are inhabited mainly by Wa ethnic groups located far from the county center, and they are known for their long history and rich homegarden management experiences.

\section{Sampling and data collection \\ Sampling strategy for the homegarden survey}

The household was the main sampling unit for the study. Sixty households were selected through a purposive sampling approach [32], following the advice of the village heads to identify the key informants. The survey was distributed to 10 households per village, accounting for at least $10 \%$ of the total households in each village. For reference, interviewees' consent was based on household availability and interest.

A total of 60 questionnaires were distributed in the six villages, and 60 valid questionnaires were conducted to collect sociodemographic information on the participating farmers regarding age, gender, and education level [22] (Table 2). According to the age categorization, 
Table 1 Characteristics of six Wa villages

\begin{tabular}{|c|c|c|c|c|c|c|}
\hline \multirow[t]{3}{*}{ Village } & \multicolumn{4}{|l|}{ Ximeng county } & \multirow{2}{*}{\multicolumn{2}{|c|}{$\begin{array}{l}\text { Cangyuan county } \\
\text { Nouliang town }\end{array}$}} \\
\hline & \multicolumn{3}{|l|}{ Zhongke town } & \multirow{2}{*}{$\begin{array}{l}\text { Mengsuo town } \\
\text { Yangluo }\end{array}$} & & \\
\hline & Dazhai & Xiaozhai & Banjing & & Heling & Papai \\
\hline Geographic location & $99^{\circ} 36^{\prime} \mathrm{E}, 22^{\circ} 47^{\prime} \mathrm{N}$ & $99^{\circ} 36^{\prime} \mathrm{E}, 22^{\circ} 47^{\prime} \mathrm{N}$ & $99^{\circ} 36^{\prime} \mathrm{E}, 22^{\circ} 43^{\prime} \mathrm{N}$ & $99^{\circ} 40^{\prime} \mathrm{E}, 22^{\circ} 39^{\prime} \mathrm{N}$ & $99^{\circ} 19^{\prime} \mathrm{E}, 23^{\circ} 12^{\prime} \mathrm{N}$ & $99^{\circ} 22^{\prime} \mathrm{E}, 23^{\circ} 18^{\prime} \mathrm{N}$ \\
\hline Elevation (m) & 918 & 862 & 802 & 1173 & 1694 & 1860 \\
\hline $\begin{array}{l}\text { Distance from the } \\
\text { county town/seat }(\mathrm{km})\end{array}$ & 27.3 & 29.3 & 14.8 & 17.4 & 40 & 45 \\
\hline Number of households & 136 & 138 & 83 & 570 & 62 & 270 \\
\hline Main industry & Crop farming, breeding & Crop farming & Crop farming & Crop farming & Crop farming & Crop farming \\
\hline
\end{tabular}

Table 2 Sociodemographic characteristics of the participants

\begin{tabular}{|c|c|c|c|c|c|c|c|c|c|}
\hline \multirow[t]{2}{*}{ Category } & \multicolumn{2}{|c|}{ Gender } & \multicolumn{3}{|l|}{ Age } & \multicolumn{4}{|c|}{ Education level } \\
\hline & Male & Female & $21-40$ & $41-59$ & $\geq 60$ & Illiteracy & Primary school & Middle school & High school \\
\hline Dazhai & 10 & 0 & 5 & 3 & 2 & 0 & 4 & 6 & 0 \\
\hline Xiaozhai & 6 & 4 & 6 & 4 & 0 & 1 & 7 & 2 & 0 \\
\hline Banjing & 8 & 2 & 4 & 5 & 1 & 2 & 5 & 3 & 0 \\
\hline Yangluo & 10 & 0 & 3 & 6 & 1 & 0 & 6 & 4 & 0 \\
\hline Heling & 10 & 0 & 6 & 4 & 0 & 0 & 4 & 4 & 2 \\
\hline Papai & 8 & 2 & 4 & 5 & 1 & 0 & 5 & 4 & 1 \\
\hline Quantity & 52 & 8 & 28 & 27 & 5 & 3 & 31 & 23 & 3 \\
\hline Percentage (\%) & 86.67 & 13.33 & 46.67 & 45.00 & 8.33 & 5.00 & 51.67 & 38.33 & 5.00 \\
\hline
\end{tabular}

$46.67 \%$ of the informants were young people (2140 years old), $45.00 \%$ were middle-aged ( $41-60$ years old) and the remaining $8.33 \%$ were elderly ( $\geq 60$ years old). A total of $86.67 \%$ of the informants were male. Regarding education level, $5.00 \%$ were uneducated, $51.67 \%$ attended primary school, $38.33 \%$ attended middle-high school, and $5 \%$ attended high school or beyond.

\section{Household survey of the management and seed system of homegardens}

Key informant interviews were carried out by using both semi-structured and unstructured techniques. The key informants included household members, elders, and agro technicians. The interviews were held to gain an indepth understanding of traditional practices associated with the management and seed system of homegardens. The first part of the interview aimed to determine the characteristics of homegardens, including their size and the cultivars grown. In the second part, seed management and sourcing, self-consumption through homegardens, and the gender of the person responsible for homegarden management were recorded. In the last part of the interview, threats and conservation issues were identified [33].

\section{Identification of traditional vegetable cultivars}

The criteria for traditional vegetables included the following: were considered heirloom crop vegetables, were local and culturally adopted, and were handed down from generation to generation [1]. With the local processes of selection and domestication, we consider that those plant species that were originally from other regions of the world and introduced centuries ago can be considered traditional species, including cultivated species and wild ones. Homegardens inventories included documentation of local names, edible parts, and eating methods of the vegetables planted. Focus group discussions (FGDs) were also held in each village to respond to an initial list of potential traditional vegetables and hybrid vegetable varieties planted in home gardens obtained from a literature review [30]. The nomenclature of all plants reported in our study followed that of Flora of China [34]. Vegetable varieties were jointly identified by local villagers, farmers, and agro technicians from the Agricultural Technology Extension Center. Ambiguous data in the reports were clarified via a FGD in each village. A final list of vegetable inventories was created, which could be further validated by farmers and local experts from the 
agricultural bureau. The homegarden system analysis and discussion that follow are based on the vegetable varieties identified.

\section{Data analysis}

The data was analyzed to determine the taxonomic diversity of traditional vegetables planted in homegardens, the edible parts, the planting frequency of key vegetables, and the household characteristics of homes with gardens. The individual vegetable varieties in 60 homegardens were determined to identify the most important varieties in homegardens. In-depth interviews were analyzed by themes according to homegarden planting practices and factors. These factors included reasons why traditional vegetable resources have been conserved in homegardens; several themes reflecting social and cultural changes emerged through thematic analyses [35].

\section{Results \\ Diversity and parts of traditional vegetables grown in Wa homegardens}

A total of 52 vegetable species belonging to 16 families and 41 genera were recorded in $60 \mathrm{Wa}$ homegardens. Of the 91 vegetable varieties, 55 were local varieties, and 36 were hybrids, accounting for $60.44 \%$ and $39.56 \%$, respectively, of all vegetable varieties grown (Table 3$)$. Among all the villages, $23 \pm 6$ (average $\pm S D$ ) traditional vegetable varieties per homegarden and $9 \pm 3$ (average \pm SD) introduced vegetable varieties per homegarden were analyzed. There were more traditional varieties than hybrids in the six villages (Fig. 2). Out of the total traditional vegetable varieties, most were members of the Cucurbitaceae (10 varieties, $18.18 \%$ ), followed by the Solanaceae (10 varieties, $18.18 \%$ ), Brassicaceae (7 varieties, $12.73 \%$ ), and Liliaceae (7 varieties, $12.73 \%$ ) (Table 3 ).

The more frequently each traditional vegetable variety was planted by local Wa villagers in their homegardens, the more important and valuable it was in the Wa community. The most frequent vegetable varieties encountered in 60 homegardens included Allium fistulosum, Allium tuberosum, Amaranthus paniculatus, Brassica chinensis, Capsicum frutescens, Nepeta cataria, and Sechium edule. Amaranthus paniculatus is widely planted in Wa homegardens owing to its drought resistance, tolerance to infertile soil, high yield, and lack of diseases or insect pressure. Allium fistulosum, Nepeta cataria, Allium tuberosum, and Capsicum frutescens are used as spices in traditional foods, which indicates that members of Wa households select and plant local spicy vegetables in their homegardens for seasoning.

On the basis of the survey, we also found that, in addition to traditionally grown vegetables, 15 wild edible vegetables within 14 families were distributed in or around the yard (Table 4). These wild vegetables are largely used as spices to enhance the aroma and flavor of dishes and have other purposes, including medicinal and ornamental ones. These wild vegetables are readily accessible along the roadside, such as Buddleja officinalis, Colocasia gigantea, Ensete wilsonii, Eryngium foetidum, Houttuynia cordata, and Mentha canadensis. Some of the wild plants can be collected at the forest edge near the village, such as Bombax ceiba, Buddleja officinalis, and Solanum americanum.

There are various ways to eat traditional vegetables, including frying them, boiling them, using them in salads, and using them for spices. These traditional eating methods essentially require Wa gardeners to grow an abundance of vegetables such that dietary needs are met. Among the 55 recorded traditional vegetable cultivars, their edible plant parts could be divided into nine categories: fruits, leaves, stalks, bulbs, flowers, seeds, roots, whole plants, and pods (Table 5). Fruits (20 species, $28.17 \%$ ), mainly from plants in the Cucurbitaceae and Solanaceae families, are the most used plant parts for nutrition. For 19 species (26.76\%), fresh leaves were the second most used part for eating by the Wa people. In households, the fresh leaves of traditional vegetables are eaten via multiple methods, including as seasonings, by frying, by boiling, and as salad ingredients. For five species $(7.04 \%)$ of 55 cultivars, the flowers were consumed as ingredients of traditional foods. These findings showed that Wa villagers have an anthophagous (flower eating) culture.

\section{Functions of Wa homegardens that provide self-sufficient vegetables and occasional income for households}

The vegetables grown in the homegardens were used mostly for self-consumption and fulfilling owners' needs. The number of households in which vegetables were grown in homegardens for self-consumption was relatively high (Fig. 3). Thirty-three out of 60 households accounting for $55 \%$ use $80 \%-100 \%$ of their vegetables. Thirteen percent of households have achieved self-sufficiency through the consumption of $50 \%-80 \%$ of the cultivated vegetables in their homegardens. Fifteen percent of households are self-sufficient through the consumption of $20 \%-50 \%$ of cultivated vegetables in their homegardens. Seventeen percent of households use $0-20 \%$ of the cultivated vegetables in their homegardens. Vegetables are used primarily for household consumption but are increasingly being used to generate cash incomes by several families. According to the interviewees, sometimes a surplus from consumption is sold to increase supplementary income for the families. 
Table 3 Traditional vegetables and their uses in Wa homegardens

\begin{tabular}{|c|c|c|c|c|c|}
\hline Scientific name & Local name & Family & Edible parts & Eating method & $\begin{array}{l}\text { Frequency } \\
\text { of } \\
\text { occurrence }\end{array}$ \\
\hline Allium chinense & Jiao tou蕌头 & Liliaceae & Bulbs & Spice & 23 \\
\hline Allium fistulosum & Pake da cong 帕科大葱 & Liliaceae & Whole plants & Spice & 7 \\
\hline Allium fistulosum & Xiao xiang cong小香葱 & Liliaceae & Whole plants & Spice & 60 \\
\hline Allium sativum & Bai pi suan白皮蒜 & Liliaceae & Bulbs & Spice & 32 \\
\hline Allium sativum & $\begin{array}{l}\text { Yongguang da suan 永 } \\
\text { 广大赫 }\end{array}$ & Liliaceae & Bulbs & Spice & 3 \\
\hline Allium hookeri & Pie cai若菜 & Liliaceae & Roots, flowers & Spice & 37 \\
\hline Allium tuberosum & Xi ye jiu cai细叶韭菜 & Liliaceae & Leaves & Fry & 60 \\
\hline Amaranthus paniculatus & Yi mi cai薏米菜 & Amaranthaceae & Fresh leaves and stalks & Fry, Boil & 60 \\
\hline Benincasa hispida & $\begin{array}{l}\text { Lao mian dong gua 老缅 } \\
\text { 冬瓜 }\end{array}$ & Cucurbitaceae & Fruits & Fry & 29 \\
\hline Benincasa hispida & $\begin{array}{l}\text { Yuesong dong gua 岳宋 } \\
\text { 冬瓜 }\end{array}$ & Cucurbitaceae & Fruits & Fry & 24 \\
\hline Brassica chinensis & Zi qing cai 紫青菜 & Brassicaceae & Leaves, stalks & Fry, Boil & 60 \\
\hline Brassica chinensis & Da qing cai 大青菜 & Brassicaceae & Leaves, stalks & Fry, Boil, Pickling & 29 \\
\hline Brassica chinensis & Wa qing cai 低族青菜 & Brassicaceae & Leaves, stalks & Pickling & 54 \\
\hline Brassica chinensis & Yuan qing cai 圆青菜 & Brassicaceae & Leaves & Pickling & 49 \\
\hline Brassica pekinensis & Pake bai cai 帕科白菜 & Brassicaceae & Leaves, stalks & Fry, Boil & 28 \\
\hline Brassica pekinensis & Nangui bai cai 南归白菜 & Brassicaceae & Leaves, stalks & Fry, Boil & 17 \\
\hline Capsicum annuum & Chao tian jiao 朝天椒 & Solanaceae & Fruits & Spice & 38 \\
\hline Capsicum annuum & Xiaozhai la 小寨辣椒 & Solanaceae & Fruits & Spice & 13 \\
\hline Capsicum annuum & Talang la jiao 他朗辣椒 & Solanaceae & Fruits & Spice & 1 \\
\hline Capsicum frutescens & Xiao mi la 小米辣 & Solanaceae & Fruits & Spice & 60 \\
\hline Capsicum frutescens & $\begin{array}{l}\text { Bai pi xiao mi la 白皮小 } \\
\text { 米辣 }\end{array}$ & Solanaceae & Fruits & Spice & 46 \\
\hline Capsicum frutescens & Lao shu la jiao 老鼠辣椒 & Solanaceae & Fruits & Spice & 1 \\
\hline $\begin{array}{l}\text { Capsicum frutescens cv. Shuan- } \\
\text { laense }\end{array}$ & Shuan shuan la 涮涮辣 & Solanaceae & Fruits & Spice & 1 \\
\hline Colocasia esculenta & Zi yu 紫芋 & Araceae & Corms & Fry, soup & 3 \\
\hline Colocasia esculenta & Banshuai yu tou 班帅芋头 & Araceae & Corms & Fry & 23 \\
\hline Colocasia esculenta & Di shui yu 滴水芋 & Araceae & Leaves, stalks & Soup, spice & 54 \\
\hline Colocasia esculenta & $\begin{array}{l}\text { Naka da ma yu 那卡大 } \\
\text { 麻芋 }\end{array}$ & Araceae & Corms & Soup & 1 \\
\hline Coriandrum sativum & Xi ye yan sui 细叶芫荽 & Apiaceae & Fresh leaves and stalks & Boil, salad, spice & 51 \\
\hline Cucumis sativus & Di huang gua 地黄瓜 & Cucurbitaceae & Fruits & Salad & 57 \\
\hline Cucurbita moschata & Jin gua 金瓜 & Cucurbitaceae & Fruits, fresh leaves, flowers & Fry & 17 \\
\hline Cucurbita moschata & $\begin{array}{l}\text { Lao mian nan gua 老缅 } \\
\text { 南瓜 }\end{array}$ & Cucurbitaceae & Fruits, fresh leaves, flowers & Fry & 13 \\
\hline Cucurbita moschata & Xiao nan gua 小南瓜 & Cucurbitaceae & Fruits, fresh leaves, flowers & Fry & 33 \\
\hline Dioscorea batatas & Zi shan yao 紫山药 & Dioscoreaceae & Tubers & Boil & 2 \\
\hline Dioscorea batatas & Shan yao 山药 & Dioscoreaceae & Tubers & Boil & 39 \\
\hline Dioscorea batatas & Xi shan yao 细山药 & Dioscoreaceae & Tubers & Boil & 19 \\
\hline Foeniculum vulgare & Hui xiang 茴香 & Apiaceae & Whole plants & Spice & 2 \\
\hline Lagenaria siceraria & Hu lu 葫芦 & Cucurbitaceae & Tender leaves & Fry & 4 \\
\hline Luffa cylindrica & Si gua 丝瓜 & Cucurbitaceae & Tender fruits & Fry & 16 \\
\hline Lycopersicon esculentum & Xiao fan qie 小番茄 & Solanaceae & Fruits & Salad & 21 \\
\hline Eryngium foetidum & A Wa yan sui 阿佤芫荽 & Apiaceae & $\begin{array}{l}\text { Whole plants, fresh leaves, and } \\
\text { stems }\end{array}$ & Spice & 18 \\
\hline Mentha haplocalyx & Bo he 薄荷 & Lamiaceae & Tender stem tips, leaves & Spice, Fry & 27 \\
\hline Momordica charantia & Menge ku gua 预阿苦瓜 & Cucurbitaceae & Fruits & Fry, Salad & 1 \\
\hline
\end{tabular}


Table 3 (continued)

\begin{tabular}{|c|c|c|c|c|c|}
\hline Scientific name & Local name & Family & Edible parts & Eating method & $\begin{array}{l}\text { Frequency } \\
\text { of } \\
\text { occurrence }\end{array}$ \\
\hline Nepeta cataria & Jing jie 荆芥 & Lamiaceae & Fresh leaves & Spice & 60 \\
\hline Pachyrhizus erosus & Hong shu 红薯 & Leguminosae & Bulbs & Fry & 3 \\
\hline Perilla frutescens & Bai su 白苏 & Lamiaceae & Leaves, stalks & Spice & 1 \\
\hline Perilla frutescens & Hei su 黑苏 & Lamiaceae & Leaves, stalks & Spice, Salad & 1 \\
\hline Pisum sativum & $\begin{array}{l}\text { Lao zhai wan dou 老寨 } \\
\text { 踠豆 }\end{array}$ & Leguminosae & Seeds & Fry & 14 \\
\hline Pisum sativum & $\begin{array}{l}\text { Wangya wan dou 王雅 } \\
\text { 踠豆 }\end{array}$ & Leguminosae & Seeds & Fry & 12 \\
\hline Pisum sativum & Hong wan dou 红踠豆 & Leguminosae & Seeds & Fry & 10 \\
\hline Raphanus sativus & Bai luo bo 白萝卜 & Brassicaceae & Roots, leaves & Pickling & 2 \\
\hline Sechium edule & Fo shou gua 佛手瓜 & Cucurbitaceae & Tender stem tips, flowers, fruits & Fry & 60 \\
\hline Solanum melongena & Bai qie 白茄 & Solanaceae & Fruits & Fry & 14 \\
\hline Solanum melongena & Zi qie 紫茄 & Solanaceae & Fruits & Fry & 40 \\
\hline Vigna unguiculata & Dou jiao 豆角 & Leguminosae & Fresh pods & Fry & 33 \\
\hline Zingiber officinale & Huang jiang 黄姜 & Zingiberaceae & Rootstocks & Spice & 54 \\
\hline
\end{tabular}

Seed sourcing and management for vegetable restoration and conservation

\section{Seed exchange networks in Wa communities}

Seed storage and protection are essential components of traditional crop-related knowledge. Traditional seeding and breeding methods can promote the protection and inheritance of local vegetable germplasm resources. Among all the traditional vegetable seed sources, approximately $78 \%$ of the 60 household seed supplies depend on the maintenance and storage of the seeds by members of the household, and an additional $8 \%$ of household seed supplies come from neighbors and relatives (Fig. 4). When vegetable plants growing in homegardens have excellent characteristics such as color, quality, or resistance to insects, neighbors, and relatives can ask to exchange seeds. In this way, local people have access to a positive, regular, and reciprocal seed exchange system in local areas. Excellent local vegetable landraces are

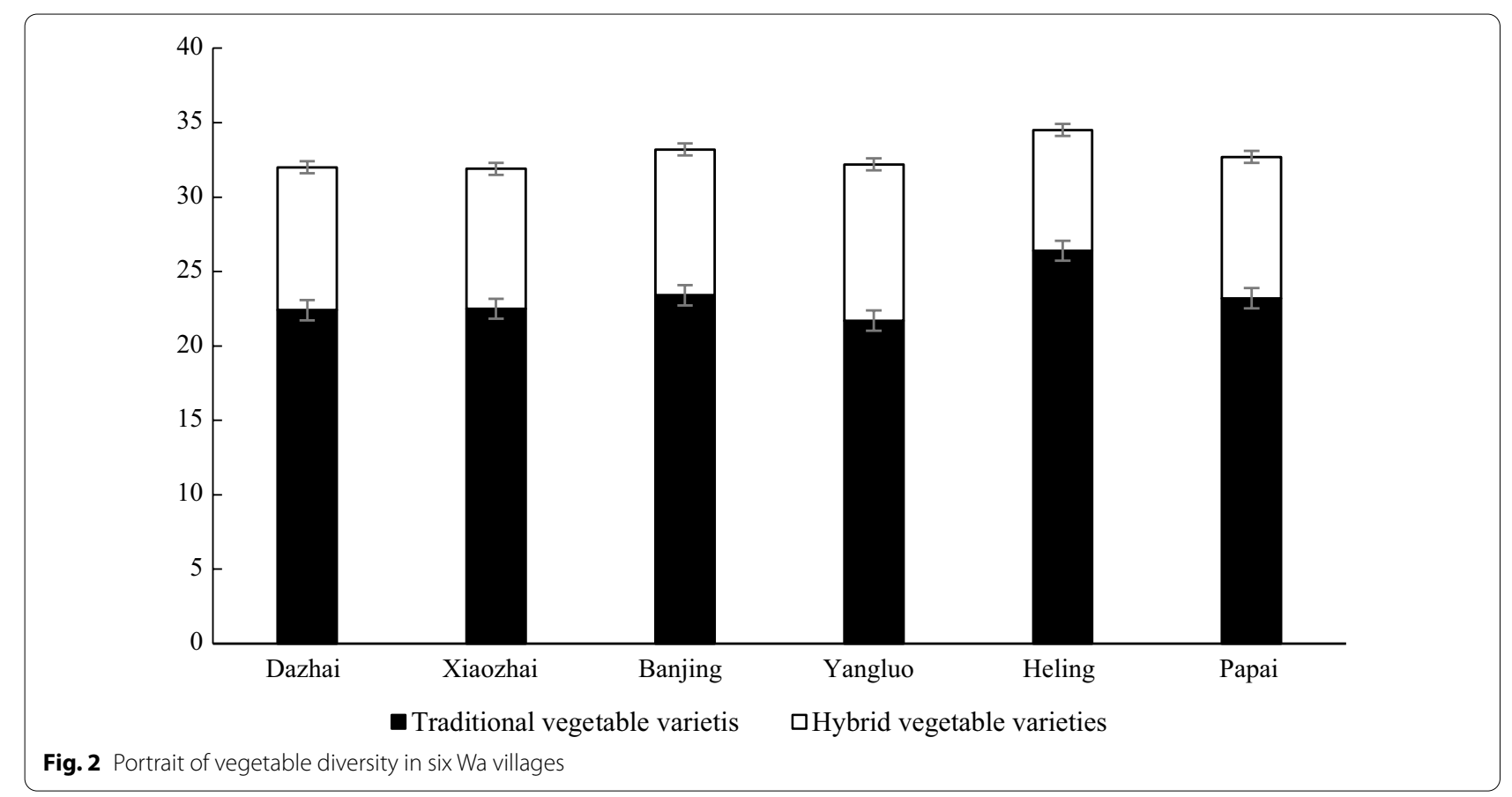


Table 4 Wild vegetable plants in/near the homegardens in Wa villages

\begin{tabular}{|c|c|c|c|}
\hline Scientific name & Family & Habitats & Other usages \\
\hline Acacia pennata & Fabaceae & Forest & \\
\hline Aralia chinensis & Araliaceae & Forest & Medicinal \\
\hline Bombax ceiba & Malvaceae & Forest, forest edge, roadside & Ornamental, textile \\
\hline Buddleja officinalis & Loganiaceae & Forest edge, roadside & Dyeing, medicinal \\
\hline Colocasia gigantea & Araceae & Roadside & \\
\hline Ensete wilsonii & Musaceae & Roadside & \\
\hline Eryngium foetidum & Apiaceae & Roadside & Seasoning \\
\hline Houttuynia cordata & Saururaceae & Roadside & Seasoning \\
\hline Mentha canadensis & Lamiaceae & Roadside & Medicinal \\
\hline Oenanthe javanica & Apiaceae & Low wetlands, shallow marshes, riverbanks & Medicinal \\
\hline Polygonum viscosum & Polygonaceae & Roadside & Seasoning \\
\hline Portulaca oleracea & Portulacaceae & Roadside & Medicinal \\
\hline Solanum americanum & Solanaceae & Forest edge, roadside & Medicinal \\
\hline Taraxacum mongolicum & Asteraceae & Roadside & Medicinal \\
\hline Zanthoxylum bungeanum & Rutaceae & Forest, forest edge & Medicinal, seasoning \\
\hline
\end{tabular}

Table 5 Numbers of species per edible plant part

\begin{tabular}{lll}
\hline Edible parts & Number of species & Percentage (\%) \\
\hline Fruits & 20 & 28.17 \\
Leaves & 19 & 26.76 \\
Stalks & 10 & 14.08 \\
Bulbs & 7 & 9.86 \\
Flowers & 5 & 7.04 \\
Seeds & 3 & 4.23 \\
Roots & 3 & 4.23 \\
Whole plants & 3 & 4.23 \\
Pods & 1 & 1.41 \\
\hline
\end{tabular}

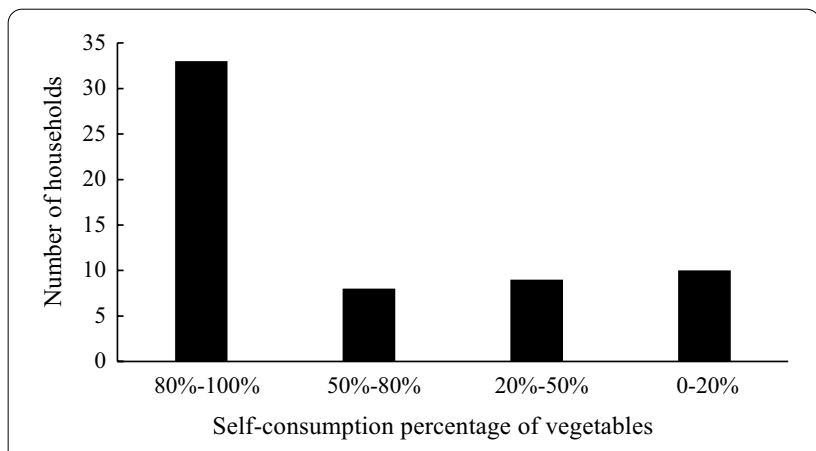

Fig. 3 Percentage of total consumed vegetables from homegardens

selected from generation to generation, which is conducive to the preservation and development of traditional vegetables.

Seed exchange practices occur not only within villages but also outside Wa communities. Exchanges

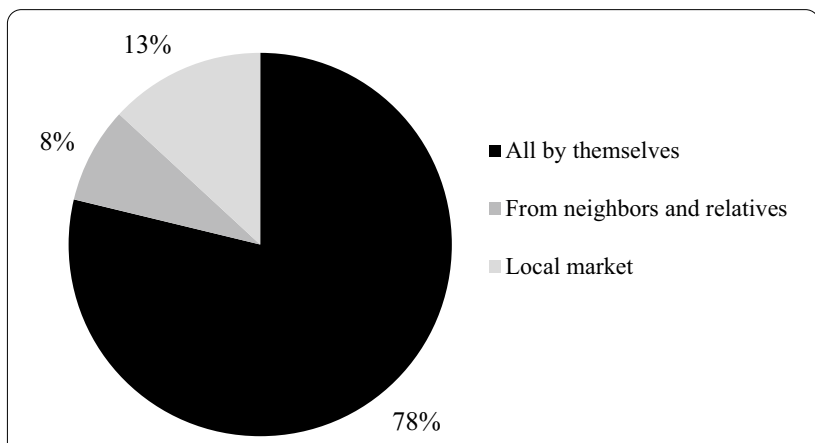

Fig. 4 Proportion of households' source of traditional vegetable seed supply

between villages and towns occur in traditional markets-farmers sell local traditional vegetable seeds in markets. Approximately $13 \%$ of households purchase local seeds from these markets. Some farmers sell traditional vegetable seeds that have better quality and set the price themselves. Like in many of the local communities, seed exchange is not the main mechanism by which seeds are acquired in Wa communities, with most seeds coming from each households' storage systems. In this context, it is not surprising that, although active, traditional seed exchange methods are fragmented and decentralized.

\section{Seed storage practices}

According to the interviews, households in Wa villages use primarily local storage methods to preserve the seeds of traditional vegetables planted in their homegardens for use the following year. Local seed storage practices 
are simple: the seeds are hung above the fireplace where meals are cooked daily in the households. This keeps the seeds directly in a dry and ventilated place to prevent mildew and predation by insects. The selection of seeds for saving is based on their color, resulting in food quality, resistance to environmental stresses, yield, and so on. Because of the simple breeding and selection methods of seeds, traditional vegetable landraces such as melons, beans, and peppers, which are easily harvested, are preserved better than are other vegetables.

Exchanges between villages and towns occur through traditional markets-farmers sell local traditional vegetable seeds for a long time in traditional markets. However, while the local families' economic conditions have gradually improved, the management of traditional vegetable seeds has become increasingly threatened. Local farmers have started to stop preserving traditional seeds and instead have been chosen to go to seed stores to buy modern hybrid seeds. Unlike in villages' traditional markets, seed stores now provide only modern hybrid seeds for farmers. One of the seed dealers said, "Farmers now prefer to buy modern seed because of the high production when they have enough money" (Interview, 16 December 2015).

\section{Gender relations concerning homegarden management}

Among the people we interviewed, most of the households had similar family structures and social relationships. With respect to homegarden management, $83 \%$ of families had a female head of household who made decisions about what kinds of vegetables to grow. Males accounted for $10 \%$ of the heads of households responsible for decision-making, and a small percentage (2\%) of the decision-making was made by elderly people. Occasionally (in $5 \%$ of families), decisions were made by both male and female household heads. With respect to the management of homegardens, less than $8 \%$ of male heads of households make decisions. Similarly, regarding seed selection and breeding, female heads of households hold more of the responsibility (88\%) (Fig. 5). The percentage of male household heads who are involved in garden management and are responsible for the selection of vegetable varieties and their preservation and cultivation is smaller than that of female household heads. However, male household heads are involved more in the decisionmaking concerning homegardens than in the actual management of those gardens.

\section{Factors influencing the conservation of traditional vegetables in homegardens}

The participants noted five main factors for continued cultivation and selection of traditional vegetables in their homegardens: having good tastes (73.33\%), honoring their ancestors by maintaining their traditions (46.67\%), being inexpensive (16.67\%), having few planting requirements $(10.00 \%)$, and being needed for cultural purposes and festivals (1.67\%) (Fig. 6).

Good taste is the fundamental reason Wa villagers keep planting traditional vegetables in their homegardens. According to Wa villagers, traditional vegetables typically have a more robust flavor than modern hybrid vegetables

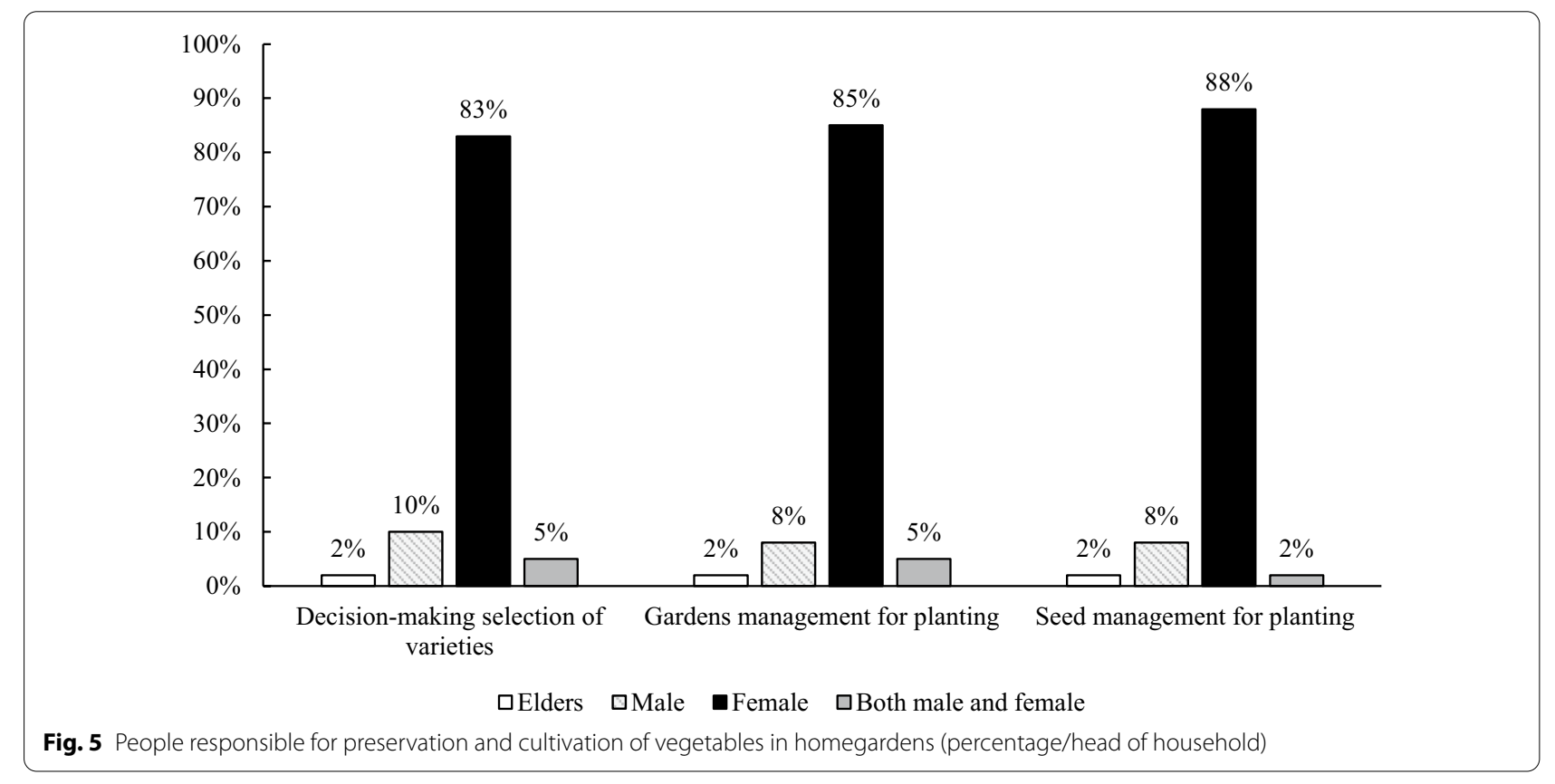




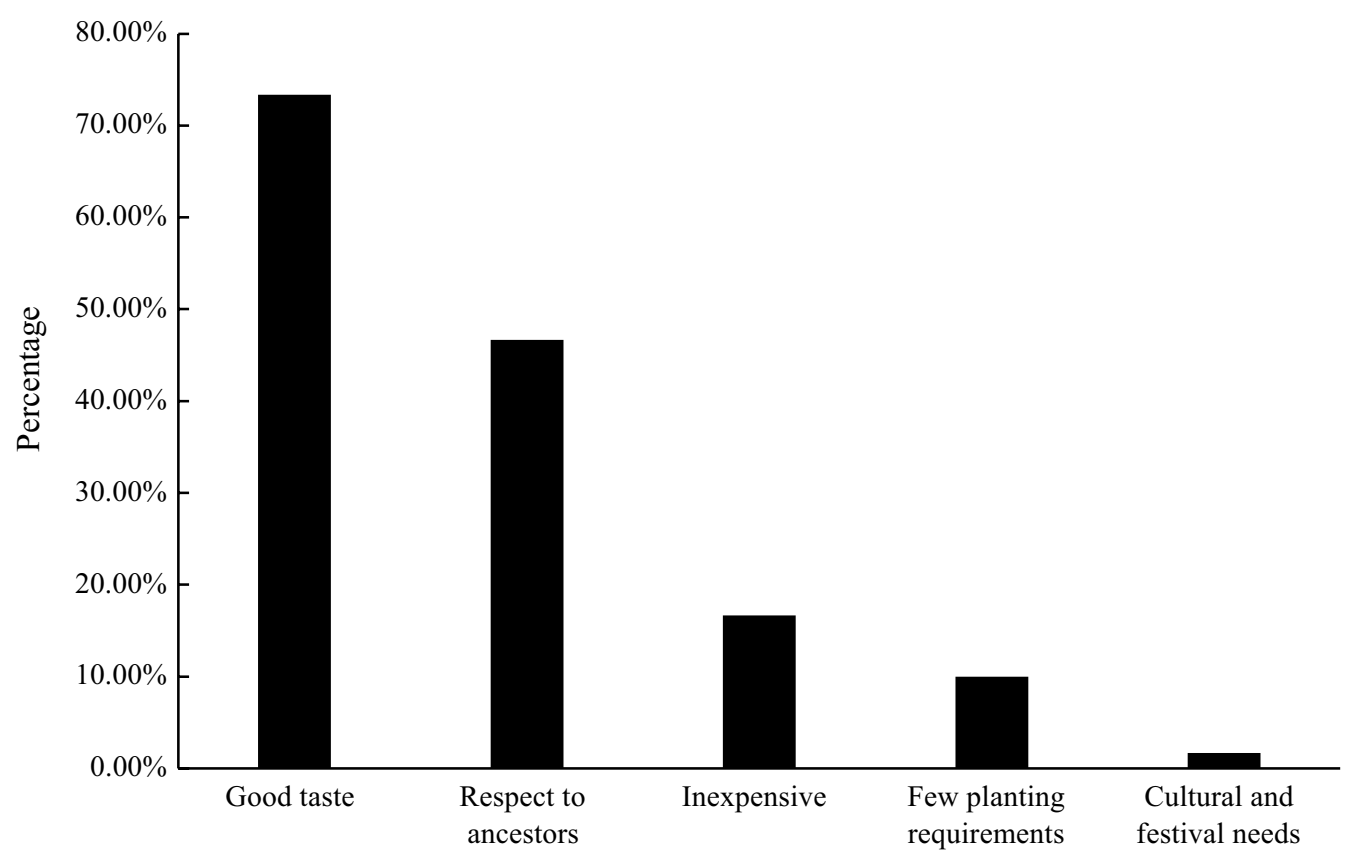

Fig. 6 Factors for continuing to grow traditional vegetables according to Wa respondents

do, which is the main reason traditional vegetables are used in their daily meals. In addition, Wa farmers believed that many traditional vegetable varieties have adapted to local soil and climatic conditions through the millennia of cultivation and have superior traits or good palatability.

Nearly half of the respondents believed that maintaining traditional vegetables was critical to honor and respect their ancestors. Wa people worship and are conscious of their ancestors; Wa people value traditional vegetable varieties and grow them across generations to honor their ancestors.

In total, $16.67 \%$ and $10.00 \%$ of Wa villagers mentioned low planting costs as a requirement for not abandoning growing traditional vegetables in their homegardens. For example, Allium fistulosum has a strong, pungent, spicy taste; is highly resistant to disease, and is easily cultivated. These features help Wa villagers save on labor and financial resources needed to manage their gardens. Local people also prefer to grow traditional varieties from seed in their homegardens and without the use of fertilizers. Even though modern hybrid vegetables are more productive than traditional vegetables are, people would have to continually spend more money buying vegetable seeds and fertilizer from the market. Resource input and outputs are not proportional in such small systems; one of the farmers said the following:

"The traditional vegetables are easier to manage in homegardens. We do not need to spend too much time on pest control and fertilization with traditional vegetables, but as for modern vegetable varieties, they are easily threatened by pests and diseases, and we need to spend time spraying pesticides and applying chemical fertilizers to achieve high yields. It's not always worth the effort." (Interview, 3 August 2015).

A total of $1.67 \%$ of the respondents mentioned that culture and festivals make traditional vegetables vital to Wa customs. Although the traditional vegetables for these needs account for only a small proportion of all the vegetables grown, they have unique characteristics and should not be ignored. For instance, Wa people traditionally eat Brassica chinensis as a traditional dish during the New Year to bless the whole family for the coming year. Moreover, Colocasia esculenta (Di shui yu) and Eryngium foetidum (A Wa yan sui) are essential seasonings due to their particular flavor within the traditional chicken rice porridge Wa dish, and it is customary for Wa families to host guests and celebrate these festivals.

\section{Discussion}

\section{Vegetable diversity and dietary culture}

As revealed in other studies of homegardens in southwestern Yunnan Province [28, 36], the Wa community has a wide variety of choices and uses of vegetables from many families and different genera in their homegardens. Wa villagers have not limited themselves to specific families and genera in their cultivation and utilization of traditional vegetables but instead use a wide range of 
species, which reflects the diversity and universality of vegetable resource use in home gardens. Such diversity reflects both the rich germplasm biodiversity cultivated by members of Wa households and the complexity of traditional dietary habits in the Wa community.

Several factors are explaining why traditional vegetables are well maintained in Wa homegardens. First, the choice of vegetables to grow is based on cultural value, dietary culture, taste preferences, market accessibility, and household needs; these choices extend to wild plants that are brought into and maintained in homegardens. Wa people's culinary culture involves mixing many vegetables and meats to enhance the taste and nutritive values of dishes, which fosters traditional knowledge of various eating methods for the different edible parts. Demand for traditional dishes also contributes to the preservation of several essential vegetable varieties. For example, Wa people prefer to eat the traditional Chicken Rice Porridge dish, which is made from fennel, tabasco pepper, mint, garlic, spring onion, cilantro, Allium hookeri, chicken, and rice. This dish is served when hosting guests and friends to show great respect, reflecting the cultural links with vegetables in Wa society. Additionally, the preference for spicy food customs has led to the maintenance of pepper varieties in the homegardens throughout history [26]. Second, the pursuit of health also promotes the diversity of vegetables used by Wa people. The daily Wa diet thus has several functions, including providing nutrients and health care knowledge [37]. Third, homegardens provide households with fresh, diverse vegetable supplies, contribute to self-sufficiency, and provide occasional income while maintaining in situ vegetable diversity. Moreover, homegardens not only maintain rich germplasm biodiversity but also enhance the inheritance of relevant ethnic and cultural practices as well as traditional knowledge [38, 39].

\section{Management of homegardens}

Seed systems are an essential component of enhancing community resilience, as seed security has several direct links to food security $[40,41]$. The circulation of seeds among farmers is central to agrobiodiversity conservation and dynamics [42]. A local seed supply enables local reproduction of seeds by farmers via local seed selection, production, and conditioning practices [43]. All of these practices depend on the ongoing transmission of traditional knowledge about seeds across generations. Local Wa people have a positive, regular, and reciprocal seed exchange system in local areas. Excellent local vegetable varieties are selected from generation to generation for preservation and the development of traditional vegetables. The seed exchange is not the primary mechanism for seed acquisition in Wa communities, with most seeds coming from each households' own storage. In this context, it is not surprising that, although active, traditional seed exchange methods are fragmented and decentralized.

Homegardens are generally managed by one individual or a couple of family members, mainly female heads of households. In one study, women were aware of homegarden conservation for the conservation of agrobiodiversity in homegardens [44]. In the families of the present study, women were generally responsible for planting and managing vegetables, and for selecting and breeding, and their knowledge of traditional vegetable cultivation and preservation was well preserved among female groups. Women in the Wa family are responsible mainly for the cultivation of vegetables in the homegarden. These findings add weight to those of previous studies that identified the significant positive influence of women on the use, management, and conservation of biodiversity through their roles in seed selection, seed storage, and the use of wild plants for food and medicine $[45,46]$.

\section{Conservation threats for traditional vegetables}

Although homegardens in Wa villages provide in situ conservation of traditional vegetables, rapid socioeconomic changes and the infiltration of foreign cultures are challenging the ongoing maintenance of traditional vegetables. As small agricultural systems, homegardens have always been neglected by policymakers. The economic demand for higher wages pulls farmers toward urban labor, and large-scale rural agricultural development has substantially reduced the rural labor force. Instead of being satisfied with the self-sufficient traditional agricultural production lifestyle, young people choose to go out to work or engage in other industries, which results in the gradual decline in traditional cultivation practices. Agricultural policies have led to the introduction or have partially subsidized hybrid vegetable varieties, and the government encourages local households to plant hybrids for increased yields. In the future, this will increase the homogeneity of vegetables planted in homegardens, which will ultimately consist primarily of modern hybrids. Either of these factors will result in the gradual disappearance of a large number of traditional vegetable varieties. A potential consequence is that local farmers, especially women, could subconsciously lose traditional knowledge of seed selection and breeding of traditional vegetables in their homegardens [47].

\section{Conclusions}

This study suggests that rich, traditional vegetable diversity is maintained in homegardens by members of households in rural villages in Wa communities in 
southwestern China. In total, 52 plant species within 16 families and 41 genera were recorded as being present in Wa homegardens in the study area. A total of 91 vegetable varieties, including 55 local varieties and 36 hybrid varieties, were recorded. The continued planting and use of traditional vegetables from diverse seed sources in homegardens contribute to the conservation of germplasm diversity. Members of households with homegardens maintain and protect the diversity of traditional vegetables through their seed management practices, which involve both saving and exchanging seeds. The cultural preference for the traditional vegetables among the Wa people plays a positive role in the protection and utilization of traditional vegetable resources; vegetables that taste better have been continued to be cultivated in homegardens. Our results reinforce the evidence that maintaining homegardens can be practical in situ conservation solution for the protection of traditional resources. Policymakers should take homegardens into consideration in land planning for rural communities to maintain small-scale agricultural function and encourage farmers, especially women, to maintain homegardens for agrobiodiversity, in situ conservation, protection of traditional varieties, and maintenance of traditional knowledge held by ethnic people in the local communities.

\begin{abstract}
Acknowledgements
We acknowledge the Wa people's traditional knowledge and respect their traditional culture and all knowledge holders. We are grateful to the agricultural bureau and agricultural vegetable station professional agricultural technology staff in Ximeng, Cangyuan, and Lancang Counties for their active collaboration and help with plant identification and conservation during the fieldwork. We also thank local farmers for their active participation; for their support; for generously sharing their knowledge with us; and for offering food, information, and good company during the fieldwork. We are also grateful to the anonymous reviewers.
\end{abstract}

\section{Authors' contributions}

$H S$, the principal researcher, conducted the field research, analyzed the data, and drafted the manuscript. As supervisors, Dr. DX and Dr. JY initiated and provided oversight of the study and input regarding its planning and provided ethics and cultural advice based on their rich experience and knowledge. Dr. $\mathrm{RH}$ revised the English language. DX, JY, and RH carefully revised the manuscript. All authors read and approved the final manuscript.

\section{Funding}

This work was supported by Minzu University of China's World-Class Universities and First-Class Disciplines Project (Grant Number Yldxxk201819) and the Biodiversity Investigation, Observation, and Assessment Program (2019-2023) of the Ministry of Ecology and Environment of China.

\section{Availability of data and materials}

All the data generated or analyzed during this study are included in this published article.

\section{Declarations}

\section{Ethics approval and consent to participate}

All informants gave verbal consent for the information they provided to be shared for academic purposes only, in accordance with the ethical standards adopted by the International Society of Ethnobiology (2008).

\section{Consent for publication}

Not applicable.

\section{Competing interests}

The authors declare that they have no competing interests.

\section{Author details}

${ }^{1}$ College of Life and Environmental Sciences, Minzu University of China, Beijing 100081, China. ${ }^{2}$ Land and Water, Commonwealth Scientific and Industrial Research Organisation, Cairns, Queensland 4878, Australia. ${ }^{3}$ Key Laboratory of Ecology and Environment in Minority Areas (Minzu University of China), National Ethnic Affairs Commission, Beijing 100081, China.

Received: 3 April 2021 Accepted: 24 August 2021

Published online: 08 September 2021

\section{References}

1. Keller GB, Mndiga H, Maass BL. Diversity and genetic erosion of traditional vegetables in Tanzania from the farmer's point of view. Plant Genet Resour. 2005;3(3):400-13. https://doi.org/10.1079/PGR200594.

2. Keatinge JDH, Yang RY, Hughes JD, Easdown WJ, Holmer R. The importance of vegetables in ensuring both food and nutritional security in attainment of the Millennium Development Goals. Food Secur. 2011;3(4):491-501. https://doi.org/10.1007/s12571-011-0150-3.

3. Ebert AW. Potential of underutilized traditional vegetables and legume crops to contribute to food and nutritional security, income and more sustainable production systems. Sustainability. 2014;6(1):319-35. https:// doi.org/10.3390/su6010319.

4. Odhav B, Beekrum S, Akula U, Baijnath H. Preliminary assessment of nutritional value of traditional leafy vegetables in KwaZulu-Natal. South Afr J Food Compos Anal. 2007;20(5):430-5. https://doi.org/10.1016/j.jfca. 2006.04.015.

5. Maroyi A. Potential role of traditional vegetables in household food security: a case study from Zimbabwe. Afr J Agric Res. 2011;6(26):5720-8. https://doi.org/10.5897/ajar11.335.

6. Solberg SØ, Seta-Waken P, Paul T, Palaniappan G, Iramu E. Patterns in the conservation and use of traditional vegetables from the New Guinean biodiversity hotspot. Agroecol Sust Food. 2018. https://doi.org/10.1080/ 21683565.2018.1489932.

7. Galluzzi G, Eyzaguirre P, Negri V. Home gardens: neglected hotspots of agro-biodiversity and cultural diversity. Biodivers Conserv. 2010;19(13):3635-54. https://doi.org/10.1007/s10531-010-9919-5.

8. Whitney CW, Tabuti JRS, Hensel O, Yeh CH, Gebauer J, Luedeling E. Homegardens and the future of food and nutrition security in southwest Uganda. Agric Syst. 2017. https://doi.org/10.1016/j.agsy.2017.03.009.

9. Rammohan A, Pritchard B, Dibley M. Home gardens as a predictor of enhanced dietary diversity and food security in rural Myanmar. BMC Public Health. 2019;1 9:1 145-57. https://doi.org/10.1186/s12889-019-7440-7.

10. Galhena DH, Freed R, Maredia KM. Home gardens: a promising approach to enhance household food security and wellbeing. Agric Food Secur. 2013. https://doi.org/10.1186/2048-7010-2-8.

11. Larios C, Casas A, Vallejo M, Moreno-Calles Al, Blancas J. Plant management and biodiversity conservation in Náhuatl homegardens of the Tehuacán Valley, Mexico. J Ethnobiol Ethnomed. 2013;9:74. https://doi. org/10.1186/1746-4269-9-74.

12. Das T, Das AK. Conservation of plant diversity in rural homegardens with cultural and geographical variation in three districts of Barak Valley, Northeast India. Econ Bot. 2015;69(1):57-71. https://doi.org/10.1007/ s12231-015-9299-6.

13. Whitney CW, Luedeling E, Tabuti JRS, Nyamukuru A, Hensel O, Gebauer J, Kehlenbeck K. Crop diversity in homegardens of southwest Uganda and its importance for rural livelihoods. Agric Hum Values. 2018;35(2):399424. https://doi.org/10.1007/s10460-017-9835-3.

14. Caballero-Serrano V, Onaindia M, Alday JG, Caballero D, Carrasco JC, McLaren B, Amigo J. Plant diversity and ecosystem services in Amazonian homegardens of Ecuador. Agric Ecosyst Environ. 2016. https://doi.org/10. 1016/j.agee.2016.04.005. 
15. Gautam R, Sthapit B, Subedi A, Poudel D, Shrestha P, Eyzaguirre P. Home gardens management of key species in Nepal: a way to maximize the use of useful diversity for the well-being of poor farmers. Plant Genet Resour. 2008;7(02):142-53. https://doi.org/10.1017/s1479262108110930.

16. Alayón-Gamboa JA, Gurri-García FD. Home garden production and energetic sustainability in Calakmul, Campeche, Mexico. Hum Ecol. 2007;36(3):395-407. https://doi.org/10.1007/s10745-007-9151-4.

17. Idohou R, Fandohan B, Salako VK, Kassa B, Gbèdomon RC, Yédomonhan $H$, Glèlè Kakaï RL, Assogbadjo AE. Biodiversity conservation in home gardens: traditional knowledge, use patterns and implications for management. Int J Biodivers Sci Ecosyst Serv Manag. 2014;10(2):89-100. https:// doi.org/10.1080/21513732.2014.910554

18. Zhu MJ, Luo BS, La B, Chen RJ, Liu FG, Long CL. Homegarden agroecosystems managed by Salar people on Qinghai-Tibet Plateau. J Ethnobiol Ethnomed. 2021;17:20. https://doi.org/10.1186/s13002-021-00448-X.

19. Perrault-Archambault $M$, Coomes OT. Distribution of agrobiodiversity in home gardens along the corrientes river, Peruvian Amazon. Econ Bot. 2008;62(2):109. https://doi.org/10.1007/s12231-008-9010-2.

20. Gbedomon RC, Salako VK, Fandohan AB, Idohou AFR, Glele Kakasmall yi UR, Assogbadjo AE. Functional diversity of home gardens and their agrobiodiversity conservation benefits in Benin, West Africa. J Ethnobiol Ethnomed. 2017;13(1):66. https://doi.org/10.1186/s13002-017-0192-5.

21. Reyes-Garcia V, Vila S, Aceituno-Mata L, Calvet-Mir L, Garnatje T, Jesch A, Lastra JJ, Parada M, Rigat M, Valles J, Pardo-de-Santayana M. Gendered homegardens: a study in three mountain areas of the Iberian Peninsula. Econ Bot. 2010;64(3):235-47. https://doi.org/10.1007/s12231-010-9124-1.

22. Gbedomon RC, Fandohan AB, Salako VK, Idohou AFR, Kakaï RG, Assogbadjo AE. Factors affecting home gardens ownership, diversity and structure: a case study from Benin. J Ethnobiol Ethnomed. 2015;11:56. https://doi.org/10.1186/s13002-015-0041-3.

23. Liu CY, Du F, Wang J, Guo SP, Xi ZP, Leng TX. Ethnobotanical survey of wild food plants used by Wa people in Cangyuan county of Yunnan province. J West China For Sci. 2012;41(5):42-9. https://doi.org/10.16473/j.cnki.xblyk x1972.2012.05.001.

24. Wang J, Li X. The triadic structure of Wa People's environmental customary law origin. In: 3rd International conference on economics, social science, arts, education and management engineering. 2017: 280-283.

25. Wang KJ. On traditional ecology culture of Wa nationality. J Honghe Univ. 2008;6(4):22-5.

26. Shao $\mathrm{H}$, Xue DY. Influence of traditional Wa culture on vegetable germplasm diversity in Yunnan Province. Biodivers Sci. 2017;25(1):36-40. https://doi.org/10.17520/biods.2016324.

27. Fu YN, Guo HJ, Chen AG, Cui JY. Household differentiation and on-farm conservation of biodiversity by indigenous households in Xishuangbanna, China. Biodivers Conserv. 2006;15(8):2687-703. https://doi.org/10. 1007/s10531-005-6318-4.

28. Shen S, Xu G, Li D, Clements DR, Zhang F, Jin G, Wu J, Wei P, Lin S, Xue D. Agrobiodiversity and in situ conservation in ethnic minority communities of Xishuangbanna in Yunnan Province, Southwest China. J Ethnobiol Ethnomed. 2017. https://doi.org/10.1186/s13002-017-0158-7.

29. Li WF, Liu FW, Wang LR, Tang CF, Qin R, Dong TW. Unique vegetable resources and traditional cultural knowledge of ethnic minorities in yunnan. J Agric. 2018;8(2):29-34.

30. Li WF, Liu FW, Gao YR, Qin R, Dong TW. Utilization and conservation on vegetable germplasm resource of minority nationality in Yunnan province. J Plant Genet Resour. 2017;18(6):1145-50. https://doi.org/10.13430/j. cnki.jpgr.2017.06.016.

31. Uprety Y, Poudel RC, Shrestha KK, Rajbhandary S, Tiwari NN, Shrestha UB, Asselin H. Diversity of use and local knowledge of wild edible plant resources in Nepal. J Ethnobiol Ethnomed. 2012;8(1):16. https://doi.org/ 10.1186/1746-4269-8-16.
32. Tongco MDC. Purposive sampling as a tool for informant selection. Ethnobot Res Appl. 2007;5:147-58.

33. Jick TD. Mixing qualitative and quantitative methods: triangulation in action. Adm Sci Q. 1979;24(4):602-11.

34. Chinese Pharmacopoeia Commission. The pharmacopoeia of the People's Republic of China. 2020th ed. Beijing: Chinese Medical Science Press; 2020.

35. Creswell JW, Poth CN. Qualitative inquiry and research design: choosing among five approaches. Thousand Oaks: Sage publications; 2017.

36. Huai HY, Xu W, Wen GJ, Bai WR. Comparison of the homegardens of eight cultural groups in Jinping County, Southwest China. Econ Bot. 2011;65(4):345-55. https://doi.org/10.1007/s12231-011-9172-1.

37. Chen M, Qu Y, Liu BL, Ye F. A study on the health care methods of homology of medicine and food of Wa people. Chin J Ethnomed Ethnopharm. 2018;27(18):1-3.

38. Liu HM, Xu ZF, Xu YK, Wang JX. Practice of conserving plant diversity through traditional beliefs: a case study in Xishuangbanna, southwest China. Biodivers Conserv. 2002;11(4):705-13. https://doi.org/10.1023/A: 1015532230442.

39. Dweba TP, Mearns MA. Conserving indigenous knowledge as the key to the current and future use of traditional vegetables. Int J Inf Manag. 2011;31(6):564-71. https://doi.org/10.1016/j.jijinfomgt.2011.02.009.

40. Aguilar-Støen M, Moe SR, Camargo-Ricalde SL. Home gardens sustain crop diversity and improve farm resilience in Candelaria Loxicha, Oaxaca, Mexico. Hum Ecol. 2008;37(1):55-77. https://doi.org/10.1007/ s10745-008-9197-y.

41. Abizaid C, Coomes OT, Perrault-Archambault M. Seed sharing in Amazonian indigenous rain forest communities: a social network analysis in three Achuar villages, Peru. Hum Ecol. 2016;44(5):577-94. https://doi.org/ 10.1007/s10745-016-9852-7.

42. Pautasso M, Aistara G, Barnaud A, Caillon S, Clouvel P, Coomes OT, Delêtre M, Demeulenaere E, De Santis P, Döring T, Eloy L, Emperaire L, Garine E, Goldringer I, Jarvis D, Joly HI, Leclerc C, Louafi S, Martin P, Massol F, McGuire S, McKey D, Padoch C, Soler C, Thomas M, Tramontini S. Seed exchange networks for agrobiodiversity conservation $A$ review. Agron Sustain Dev. 2013;33(1):151-75. https://doi.org/10.1007/ s13593-012-0089-6.

43. Almekinders CJM, Louwaars NP, de Bruijn GH. Local seed systems and their importance for an improved seed supply in developing countries. Euphytica. 1994;78(3):207-16. https://doi.org/10.1007/bf00027519.

44. Akhter S, Alamgir M, Sohel MSI, Rana MP, Ahmed SJM, Chowdhury $\mathrm{MSH}$. The role of women in traditional farming systems as practiced in homegardens: a case study in Sylhet Sadar Upazila, Bangladesh. Trop Conserv Sci. 2010;3(1):17-30. https://doi.org/10.1177/194008291000300 103.

45. Rocheleau DE. Gender and biodiversity: a feminist political ecology perspective. IDS Bull. 1995;26(1):9-16. https://doi.org/10.1111/j.1759-5436. 1995.mp26001002.x.

46. Momsen JH. Gender and biodiversity: a new approach to linking environment and development. Geogr Compass. 2007;1(2):149-62. https://doi. org/10.1111/j.1749-8198.2007.00011.x.

47. Yang YH, Bai KY, Jarvis D, Long CL. Xishuangbanna cucumber landraces and associated traditional knowledge. Biodivers Sci. 2019;27(7):743-8. https://doi.org/10.17520/biods.2019108.

\section{Publisher's Note}

Springer Nature remains neutral with regard to jurisdictional claims in published maps and institutional affiliations. 